\title{
Analisis Tingkat Literasi Keuangan, Experienced Regret, dan Risk Tolerance pada Keputusan Investasi di Batam
}

\author{
Hikmah, SE., M.Si \\ Universitas Putera Batam \\ Hikmah@puterabatam.ac.id \\ Mauli Siagian, S.Kom., M.Si \\ Universitas Putera Batam \\ Mauli@puterabatam.ac.id

\section{Parlindungan Siregar} \\ Universitas Putera Batam \\ siregarnamata@gmail.com
}

\begin{abstract}
Abstrak Perkembangan perekonomian saat ini semakin berkembang dengan pesat seiring dengan perkembangan industri 4.0. Berada dalam revolusi industri saat ini sangat berkaitan dengan literasi keuangan yang ada di Indonesia terutama berkaitan dengan investasi dikota Batam. Sebagaian masyarakat berpikir untuk memperoleh pendapatan dari luar gaji selain dari tempat mereka bekerja. Salah satu jalan untuk memperoleh yakni dengan melakukan investasi. Dalam penelitian ini bertujuan untuk mengetahui tingkat literasi keuangan, experienced regret, dan risk tolerance pada keputusan investasi di Kota Batam. Populasi dalam penelitian ini adalah 2 kecamatan yang ada di Kota Batam yaitu Kecamatan Batu aji, kecamatan Sagulung. Metode pengumpulan data mengunakan kuesioner. Dengan mengunakan rumus Jacob cohen maka sampel dalam penelitian ini 204 respoenden. Reseponden dalam penelitian ini adalah masyarakat yang pernah melakukan investasi. Teknik penentuan sampel yang digunakan adalah purposive sampling. Adapun metode analisis yang digunakan mengunakan SEM dengan aplikasi SmartPLS. Hasil penelitian menunjukkan bahwa literasi keuangan berpengaruh secara signifikan dan positif terhadap keputusan investasi di kota Batam, experienced regret berpengaruh secara signifikan dan positif terhadap keputusan investasi di kota Batam, risk tolerance berpengaruh secara signifikan dan positif terhadap investasi di kota Batam;
\end{abstract}

Kata Kunci Tingkat literasi keuangan; experienced regret; risk tolerance; keputusan investasi

\section{PENDAHULUAN}

Perkembangan perekonomian saat ini semakin berkembang dengan pesat seiring dengan perkembangan industri 4.0. Berada dalam revolusi industri saat ini sangat berkaitan dengan literasi keuangan yang ada di Indonesia terutama berkaitan dengan 
investasi dikota Batam. Masyarakat di Indonesia sebagian masih lebih cenderung untuk menabung dibandingkan dengan melakukan investasi seperti investasi di bursa saham. Sangat berbeda dengan masyarakat di luar negeri yang lebih tertarik berinvestasi di investasi jangka panjang. Investasi sendiri merupakan suatu kegiatan yang dilakukan seseorang dengan melakukan penanaman modal baik yang dilakukan secara langsung maupun yang dilakukan secara tidak langsung dengan tujuan atau harapan bahwa dikemudian hari nanti akan mendapatkan keuntungan atau imbal hasil dari kegiatan investasi yang dilakukan tersebut.

Semakin meningkatknya minat masyarakat berinvestasi malah dimanfaatkan oleh sekelompok orang untuk melakukan kejahatan dalam bidang keuangan yang berkedok investasi. Berdasarkan data dari otoritas jasa keuangan (OJK) dari Januari- April 2018 terdapat 72 investasi yang tidak terdaftar izin (bodong) (OJK, 2018). Masyarakat sebagian memiliki dana yang bisa diinvestasikan namun mereka belum memiliki pengetahuan terkait dengan instrument keuangan yang bisa dipilih untuk melakukan investasi. Dengan pengetahuan yang terbatas maka banyak masyarakat yang akhirnya terjerat kedalam investasi yang illegal yang menjanjikan tingkat keuntungan dimasa yang akan datang jauh lebih besar, padahal investasi tersebut tidak terdaftar pada otoritas jasa keuangan yang ada di Indonesia. Oleh karena itu masyarakat harus mampu memiliki tingkat pengetahuan tentang instrument-instrument keuangan yang layak untuk dilakukan investasi. Dalam hal ini masyarakat harus memiliki pengetahuan akan instrument investasi dan pengalaman sehingga bisa menentukan keputusan investasi yang terbaik melalui literasi keuangan.

Literasi keuangan merupakan suatu hal yang tidak dapat dipisahkan dalam aktivitas atau kegiatan seseorang di karenakan literasi keuangan adalah alat yang sangat berguna dalam membuat suatu keputusan keuangan yang terorganisir. Otoritas Jasa Keuangan (OJK) menyatakan bahwa tingkat pengetahuan masyarakat baik konvesnional maupun syariah itu masih sangat rendah bahkan memprihatinkan. Otoritas Jasa Keuangan (OJK) mencatat, bahwa pada tahun 2018 indeks literasi keuangan masyarakat Indonesia masih rendah. Dengan hasil survei nasional literasi dan inklusi keuangan tahun 2018 , bahwa terdapat $67,8 \%$ masyarakat yang menggunakan produk dan layanan keuangan, namun hanya 29,7\% masyarakat yang well literate.

Berdasarkan hasil survei literasi 2018 yang dilakukan OJK, indeks literasi keuangan syariah baru 8,11 persen. Artinya, setiap 100 orang baru delapan orang yang memahami sektor jasa keuangan syariah. Sedangkan tingkat inklusi atau masyarakat yang menggunakan keuangan syariah untuk pendanaan baru 11,06 persen. Artinya dari 100 masyarakat Indonesia hanya 11 orang yang menggunakan transaksi keuangan di sektor keuangan syariah. Literasi keuangan masyarakat dan pengelolaan keuangan bagi setiap keluarga Indonesia adalah sesuatu hal yang sangat penting dikarenakan merupakan suatu pilar perekonomian, dimana keluarga memberikan pengaruh yang sangat besar terhadap kesehatan keuangan suatu Negara secara keseluruhan.

Persepsi seseorang terhadap risiko akan akan mempengaruhi pengambilan keputusan investasi. Persepsi merupakan suatu proses dimana seseorang mengelola dan menginterpretasikan pengalaman sensor mereka untuk memberikan arti terhadap lingkungan mereka (Robbins and Judge, 2010:175). Persepsi risiko bisa dibentuk secara sosial, Williamson \& Weyman (2005) mendefinisikan persepsi risiko merupakan akumulasi dari berbagai faktor yang menjadi dasar terhadap sebagai hasil dari 
perbedaaan dalam pengambilan keputusan terhadap probabilitas kerugian yang mungkin terjadi. Pola Perilaku investor dalam pengambilan keputusan sangat pengaruhi oleh adanya sikap subyektif yang dimiliki terhadap risiko dan pendapatan investasi itu sendiri (Wulandari, 2016). Penelitian sebelumnya yang dilakukan oleh Droms (1987), Kinerson dan Bailey (2005) dan Yohnson (2008) ditemukan bahwa variabel risk tolerance berpengaruh signifikan terhadap keputusan investasi. Dapat disimpulkan bahwa risk tolerance secara keseluruhan mempengaruhi keputusan investasi. Namun, masing-masing level dari risk tolerance (tinggi/rendah) memiliki perbedaan pengaruh terhadap keputusan investasi (Pujiyanto \& Mahastanti, 2017).

Kota Batam dengan posisi geografis yang sangat startegis dari Malaysia, menyebabkan beberapa investasi yang masuk ke Indonesia dari Malaysia. Dengan kurangnya pengetahuan masyarakat kota Batam tentang literasi keuangan dalam investasi menyebabkan terjadi korban dari investasi yang illegal seperti pada tahun 2018 di kota Batam ada sekitar 500 orang yang menjadi korban atas investasi yang dilakukan pada PT Maju Aset Indonesia (MAI) dengan kerugian mencapai Rp 20 miliar lebih. PT MAI mengenalkan diri sebagai perusahaan yang bergerak di bidang perakitan sayap pesawat. Dengan latar belakang tersebut, maka penulis tertarik untuk melakukan penelitian untuk mengetahui pengaruh tingkat literasi keuangan, experienced regret dan risk tolerance terhadap pemilihan jenis investasi.

\section{LANDASAN TEORI}

\section{Literasi keuangan}

Pada bidang Ilmu manajemen keuangan literasi keuangan sangat erta kaitannya dengan personal atau individu yang meliputi tentang pengelolaan kekayaan yang baik, perencaaan dalam melakukan investasi dan keputusan untuk menentukan pilihan dalam melakukan investasi baik investasi jangka panjang maupun investasi jangka pendek. Literasi keuangan sangat berperan dalam peningkatan kualitas hidup individu dalam keuangan dan perilaku mengatur finansial untuk perencanaan keuangan dimasa yang akan datang yang jauh lebih baik dibandingkan pada masa sekarang ini. Saat ini masyarakat sudah bisa memilih berbagai investasi yang dapat dilakukan seperti investasi di pasar modal yaitu melalui investasi saham dan obligasi atapun investasi lainnya seperi tanah, emas atau investasi lainnya yang dapat memberikan keuantungan atau imbal hasil yang lebih baik dimasa yang akan datang. Pengertian literasi keuangan menurut Peraturan Otoritas Jasa Keuangan (POJK) Nomor 76/POJK/07/2016 adalah pemahaman, skill, dan rasa yang mampu mempengaruhi perilaku dari masyarakat sehingga bisa membuat keputusan keuangan dan investasi yang tepat untuk meningkatkan kesejahteraan dan kualitas hidup.(Otoritas Jasa Keuangan, 2016). Pengetahuan keuangan harus dimiliki oleh seseorang agar memiliki kemampuan pemahaman rasa percaya diri sehingga dengan pengetahuan keuangan yang dimiliki dapat membuat keputusan keuangan yang tepat. Pengukuran tingkat pemahaman dan pengetahuan menjadi sangat penting pada saat ini karena masyarakat tidak hanya menetahui informasi tetapi masyarakat juga mampu menerapkan dan mengaplikasinnya dengan tepat. (Putra, Ananingtiyas, Sari, Dewi, \& Silvy, 2016). Adapun tahapan literasi keuangan seseorang dibagi menjadi 4 jenis yaitu (Otoritas Jasa Keuangan, 2014), yaitu: Well Literate, Suff Literate, Less Literate, Not Literate 


\section{Experienced Regret}

Experienced regret pada masyarakat seringkali dialami dan menjadi permasalahan bagi seorang investor. Experinced regret adalah suatu perasaan yang dirasakan oleh seseorang dari pengalaman yang telah dilakukan yang menyebabkan orang tersebut merasa kecewa dan menyesal terhadap keputusan yang yang telah dilakukan pada investasi dan belum siap menerima atas resiko yang didapatkan dari investasi terdahulu (Pujiyanto \& Mahastanti, 2017). Seseorang yang menyukai akan investasi yang beresiko tinggi tentunya akan melakukan analisis atas resiko-resiko yang akan muncul dalam melakukan investasi. Seorang investor yang memiliki experinced regret yang tinggi tentunya telah mempunyai pengalaman investasi yang sudah lama sehingga mampu menerapkan pengalaman yang didapatkan di masa lalu pada saat melakukan investasi pada saat sekarang ini. Investor yang yang experinced regret tinggi akan nantinya lebih condong akan memilik investasi yang memiliki resiko tinggi. Seorang yang telah bertahun tahun telah melakukan investasi dan pernah gagal dalam mendapatkan keuntungan atau imbal hasil yang diinginkan maka individu atau orang tersebut dikatakan baru memiliki experinced regret. Dengan demikian individu yang akan lebih berhati-hati pada waktu selanjutnya apabila akan melakukan investasi berikutnya. Sehingga dapat disimpulkan bahwa apabila seseorang atau invidu yang memiliki experinced regret yang lebih tinggi maka dapat disimpulkan seseorang tersebut nantinya akan memiliki risk averse. (Wulandari, 2016 Adapun Indikator variabel experinced regret adalah adalah pengalaman seseorang menderita kerugian dalam melakukan investasi, Adanya rasa penyesalan dalam melakukan investasi, akibat dari adanya pengalaman kegagalan untuk investasi selanjutnya.).

\section{Risk tolerance}

Setiap individu atau investor memiliki persepsi yang berbeda berkaitan dengan tingkat toleransi. Risk tolerance atau toleransi risiko merupakan merupakan tingkatan kemampuan yang dimiliki oleh seseorang yang mampu mereka terima dalam suatu resiko yang terjadi. Apabila dikaitkan dengan referensi investor maka resiko dapat dibedakan menjadi 3 yaitu investor yang suka dengan tantangan resiko, investor yang menghindari resiko dan investor yang memiliki sikap netral terhadap resiko Apabila investor yang suka menghindari resiko maka investor tersebut tidak menyukai investasi yang memiliki resiko tinggi dan mereka berusaha untuk menghindari resiko tersebut, namun kebalikannya apabila orang tersebut lebih menyukai tantangan maka individu tersebut tidak menghindari resiko (risk taker) (Wulandari, 2016). Bagi investor yang spekulatif dan memiliki sikap agresif untuk pengambilan keputusan maka individu mengetahui adanya hubungan antara return dan resiko adalah positif.

Adapun jenis yang kedua adalah investor yang berada di kategori netral terhadap adanya resiko (risk neutral), investor pada kategori kedua ini adalah investor yang meminta kenaikan jumlah investasi yang sama dari setiap kenaikan resiko investasi yang dilakukan. Jenis investor yang kedua ini adalah investor yang memiliki keperidian dan sikap atas resiko yang lebih hati-hati dalam melakukan investasi dan menghindari resiko. Jenis investasi yang ketiga adalah adalah investor yang tidak menyukai dan selalu menghindari resiko atau biasa disebut dengan (risk averter), merupakan seseorang atau invividu yang apabila dihadapkan pada dua investasi yang sama, dengan tingkat pengembalian yang sama maka mereka akan lebih memilih yang memiliki 
tingkat resiko yang memberikan tingkat pengembalian yang lebih tinggi dengan pemilihan tingkat resiko yang lebih rendah. Adapun perbedaan dalam pemberian toleransi bisa disebabkan oleh beberapa faktor seperti umur, status pekerjaan, tingkat pendapatan, dan tingkat kesejahteraan ataupun pendapatan yang dimiliki dimasa yang akan datang. Dengan adanya uraian diatas maka dapat simpulkan bahwa risk tolerance memiliki pengaruh terhadap pengembalian keputusan investasi.

\section{Keputusan investasi}

Keputusan investasi merupakan tindakan suatu keputusan dari kebijakan yang diambil dalam melakukan investasi pada aset atau modal yang melakukan investasi yang akan memberikan profit dimasa yang akan datang (Wulandari, 2016). Dalam pengambilan keputusan investasi terdapat dua sikap yaitu sikap rasional dan irasional. Adapun sikap rasional adalah sikap dari seseorang atau investor yang berpikir sesuai akal sehat dan bisa diterima oleh orang lain, sedangkan sikap yang irrasional adalah pola pikir dari seseorang yang tidak sesuai dengan akal sehat dan terkadang tidak diterima oleh orang lain atas keputusan yang diambil, khususnya keputusan dalam melakukan investasi baik dipasar modal ataupun di pasar keuangan lainnya. Seorang investor yang memiliki sikap rasional terhadap keputusan investasi maka dalam pengambilan keputusan investasi selalu didasari dengan literasi keuangan. Misalnya apabila seseorang yang akan melakukan investasi maka akan mengunakan informasi yang ada untuk mengambil keputusan yang tepat dalam melakukan investasi. Seseorang yang memiliki pola pikir rasional maka akan mempertimbangkan resiko dan keuantungan yang akan didapatkan. Sedangkan bagi investor yang memiliki sikap irasional maka keputusannya biasanya didasari dengan beberapa faktor seperti faktor psikologis dan faktor demografi. Dalam keputusan investasi terdapat beberapa hal yang menjadi landasan seseorang dalam mengambil keputusan yaitu (1) Tingkat return menjadi motivasi dan mendasari seseorang melakukan investasi.. Kedua risk atau risiko, semakin besar return yang diharapkan dari sebuah jenis investasi maka akan semakin tinggi pula risikonya. Ketiga adalah hubungan antara return dan resiko. Hubungan tingkat resiko dan tingkat return diharapkan linier atau searah (Pujiyanto \& Mahastanti, 2017)

\section{METODOLOGI PENELITIAN}

Populasi pada penelitian yang dilakukan adalah masyarakat Kota Batam yang pernah melakukan investasi. Sampel diambil dari dua (2) kecamatan sebagai perwakilan keseluruhan masyarakat yaitu kecamatan Batu aji dan kecamatan sagulung. Adapun sampel yang dipakai pada penelitian ini adalah metode purposive sampling yang mengunakan kriteria yaitu calon investor atau investor yang memiliki penghasilan minimal Rp 4.000.000/bulan. Untuk tahapan berikutnya dilakukan pengambilan sampel dilakukan yang menggunakan metode convenience sampling, jumlah responden sebanyak 204 orang

\section{HASIL PENELITIAN}

1. Pengujian Uji Indikator/ Outer Model 


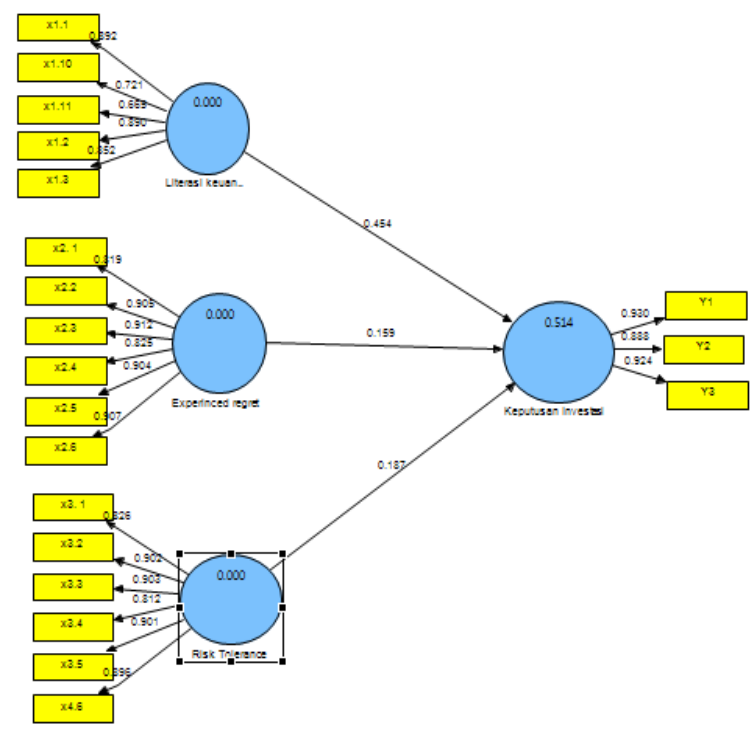

Berdasarkan data pada gambar diatas dapat dijelaskan bahwa masing-masing indicator dari variabel penelitian memiliki nilai outer loading $>0,7$. Dari data menggambarkan bahwa setiap indikator menunjukkan bahwa tidak ada indikator variabel yang nilai outer loading-nya di bawah 0,5 sehingga dapat simpulkan bahwa semua indikator dinyatakan layak atau valid digunakan dalam melakukan penelitian selanjutnya. Dari data yang dijelaskan diatas bahwa varaibel memiliki tingkat validitas yang tinggi, sehingga sudah memenuhi convergent validity. Oleh karena itu analisis dapat dilanjutkan pada uji Discriminant Validity. Demikian juga pengujian cross loading pada masing-masing variabel penelitian dimana nilai cross loading yang terbentuk lebih besar dibandingkan nilai cross loading variabel yang lainnya. Sesuai dengan hasil yang diperoleh dinyatakan bahwa indiaktor-indikator yang digunakan pada penelitian ini sudah memiliki discriminant validity yang layak dalam menyusun variabelnya masing-masing.

Average Variant Extracted (AVE)

\begin{tabular}{|c|c|c|}
\hline Variabel & AVE & Communality \\
\hline Literasi keuangan & 0.773522 & 0.773522 \\
\hline Exprienced regret & 0.835878 & 0.835878 \\
\hline Risk tolerance & 0.655348 & 0.655348 \\
\hline Keputusan Investasi & 0.764382 & 0.764384 \\
\hline
\end{tabular}

Berdasarkan tabel diatas, dapat dilihat bahwa diketahui bahwa literasi keuangan, experinced regret, Risk tolerance dan keputusan investasi memiliki nilai average variant extracted $>0,5$. Dengan demikian dapat dikatakan setiap variabel telah memiliki discriminant validity yang baik. Nilai Communality lebih besar daripada daripada 0.5.

Composite Reliability

\begin{tabular}{|c|c|}
\hline Variabel & AVE \\
\hline Literasi keuangan & 0.655348 \\
\hline
\end{tabular}




\begin{tabular}{|c|c|}
\hline Experinced regret & 0.773522 \\
\hline Risk tolerance & 0.764382 \\
\hline Keputusan Investasi & 0.835878 \\
\hline
\end{tabular}

Berdasarkan sajian data pada tabel di atas, dapat dillihat bahwa nilai composite reliability semua variabel penelitian $>0,6$. Hasil ini menunjukkan bahwa masingasing variabel telah memenuhi composite realibility sehingga dapat disimpulkan bahwa keseluruhan variabel memiliki tingkat realibilitas yang tinggi.

Cronbach Alpha

\begin{tabular}{|c|c|}
\hline Variabel & Cronbach Alpha \\
\hline Literasi keuangan & 0.866419 \\
\hline Experinced regret & 0.940947 \\
\hline Risk tolerance & 0.937878 \\
\hline Keputusan Investasi & 0.901686 \\
\hline
\end{tabular}

Berdasarkan tabel diatas dapat dilihat bahwa nilai dari cronbach alpha dari masingmasing variabel penelitian > 0,7. Hasil ini dapat menunjukkan bahwa masing-masing variabel penelitian telah memenuhi persyaratan nilai cronbach alpha, dengan demikian dapat disimpulkan bahwa keseluruhan variabel memiliki tingkat reliabilitas yang tinggi.

T-Statistic

\begin{tabular}{|c|c|c|c|c|c|}
\hline & $\begin{array}{c}\text { Original } \\
\text { Sample (O) }\end{array}$ & $\begin{array}{c}\text { Sample } \\
\text { Mean (M) }\end{array}$ & $\begin{array}{c}\text { Standard } \\
\text { Deviation } \\
\text { (STDEV) }\end{array}$ & $\begin{array}{c}\text { Standard } \\
\text { Error } \\
\text { (STERR) }\end{array}$ & $\begin{array}{c}\text { T-Statistics } \\
(\mid \mathbf{O} \text { (STERR|) }\end{array}$ \\
\hline $\begin{array}{c}\text { Experinced } \\
\text { regret-> } \\
\text { Keputusan } \\
\text { Investasi }\end{array}$ & 0.158865 & 0.162966 & 0.159068 & 0.159068 & 2.998719 \\
\hline $\begin{array}{c}\text { Literasi } \\
\text { keuangan -> } \\
\text { Keputusan } \\
\text { Investasi }\end{array}$ & 0.454046 & 0.464204 & 0.1061098 & 0.106198 & 4.275458 \\
\hline $\begin{array}{c}\text { Risk } \\
\text { tolerance -> } \\
\text { Keputusan } \\
\text { Investasi }\end{array}$ & 0.186746 & 0.173273 & 0.159338 & 0.159338 & 2.172011 \\
\hline
\end{tabular}

Dari diatas, hubungan antara literasi keuangan dengan keputusan investasi adalah signifikan dengan T-Statistics berada diatas 1,96 yaitu sebesar 2.998719. Nilai original 
sample (O) adalah positif yaitu sebesar 0,158865 yang menjelaskan bahwa hubungan antara literasi keuangan terhadap keputusan investasi adalah positif. Dengan demikian, hipotesis H1 dalam penelitian ini yang menjelaskan bahwa "literasi keuangan berpengaruh terhadap keputusan investasi" diterima. Hasil ini sesuai dengan hasil penelitian (Wulandari, 2016) yang mengatakan bahwa literasi keuangan berpengaruh terhadap keputusan investasi. Dari tabel diatas, hubungan antara experienced regret dengan keputusan investasi adalah signifikan dengan T-Statistics berada diatas 1,96 yaitu sebesar 4.275458 Nilai original sample (O) adalah positif yaitu sebesar 0.454046 yang menjelaskan bahwa hubungan antara experienced regret terhadap keputusan investasi adalah positif. Dengan demikian, hipotesis $\mathrm{H} 1$ dalam penelitian ini yang menjelaskan bahwa "experienced regret berpengaruh terhadap keputusan investasi" diterima. Hasil ini sesuai dengan hasil penelitian (Putra et al., 2016) bahwa experinced regret berpengaruh terhadap keputusan Investasi. Dari tabel diatas, hubungan antara risk tolerance dan keputusan investasi adalah signifikan dengan T-Statistics berada diatas 1,96 yaitu sebesar 2.172011. Nilai original sample (O) adalah positif yaitu sebesar 0.186746 yang menjelaskan bahwa hubungan antara risk tolerance dan keputusan investasi adalah positif. Dengan demikian, hipotesis $\mathrm{H} 3$ dalam penelitian ini yang menjelaskan bahwa "risk tolerance dan keputusan investasi" diterima. Hasil ini sesuai dengan hasil penelitian (Putra et al., 2016), (Wulandari, 2016) bahwa risk tolerance memiliki pengaruh positif dan signifikan terhadap keputusan investasi.

\section{KESIMPULAN}

Berdasarkan hasil penelitian dan pembahasan yang telah dilakukan dan dijelaskan dibab sebelumnya dapat disimpulkan bahwa:

1. Literasi keuangan berpengaruh secara signifikan dan positif terhadap keputusan investasi di Kota Batam.

2. Experinced regret berpengaruh secara signifikan dan positif terhadap keputusan investasi Kota Batam.

3. Risk tolerance terdapat pengaruh secara signifikan dan positif terhadap keputusan investasi di Kota Batam.

\section{DAFTAR PUSTAKA}

Arsanti, C. (2018). Analisis pengaruh Literasi keuangan terhadap perilaku keuangan Mahasiswa. Perbanas Jurnal, 3(2), 110-122.

Lofian. (2016). Identifikasi Faktor Eksternal Dan Faktor Internal Yang Berpengaruh Terhadap Kinerja UKM Mebel dan Rotan di Jepara. Disprotek, 5(2), 8-15.

Munizu, M. (1990). Pengaruh Faktor-Faktor Eksternal dan Internal Terhadap Kinerja Usaha Mikro dan Kecil ( UMK ) di Sulawesi Selatan.

Otoritas Jasa Keuangan. (2016).

Pujiyanto, N., \& Mahastanti, L. A. (2017). Regret Aversion dan Risk Tolerance dalam Keputusan Investasi. Journal Busnis Dan Manajemen, 2.

Putra, I. P. S., Ananingtiyas, H., Sari, D. R., Dewi, A. S., \& Silvy, M. (2016). Pengaruh tingkat literasi dan risk tolerance pada pemilihan jenis investasi. Journal of Business and Banking, 5(2). https://doi.org/10.14414/jbb.v5i2.548

Wulandari, D. A. (2016a). Studi experienced Regret, Risk Tolerance, Overconfidance dan risk perception pada pengambilan leputusan investasi Dosen ekonomi. Journal 
E-ISSN : 2599-3410 | P-ISSN : 2614-3259

DOI : https://doi.org/10.36778/jesya.v3i1.142

of Business and Banking, 4(1), 55-66.

Wulandari, D. A. (2016b). Studi Experienced Regret, Risk Tolerance, Overconfidance, $4(1), 55-66$. 